\title{
ROLE OF RAMOSETRON AND ONDANSETRON IN LUCS AND LOWER LIMB SURGERY UNDER SPINAL ANAESTHESIA
}

\author{
Utpal Kumar Ray ${ }^{1}$, Prasanta Kumar Mandal ${ }^{2}$
}

${ }_{1}^{1}$ Assistant Professor, Department of Anaesthesia, Murshidabad Medical College, Berhampur.

${ }^{2}$ Associate Professor, Department of Orthopaedics, BSMC, Bankura.

\begin{abstract}
BACKGROUND
ABSTRACT

Death or serious morbidity resulting directly from anaesthesia is now extremely rare. However, postoperative nausea and vomiting (PONV) is still very common. Therefore, every anaesthetist must be aware of the physiology of PONV and its consequences, causes, associated factors and management. Postoperative Nausea and Vomiting (PONV) after spinal anaesthesia for caesarean delivery and lower limb surgery (LLS) are distressing to both patients and surgeons. Spinal anaesthesia has been shown to be an easy, rapid and safe technique.

Objective- To determine the efficiency of ramosetron and ondansetron in terms of prevention of nausea and vomiting intraoperatively and postoperatively in LSCS \& LLS patients under spinal anaesthesia.
\end{abstract}

\section{MATERIALS AND METHODS}

Study Design- Randomised, double-blind study.

In this randomised, double-blind study, 60 patients received either ondansetron (4 mg) or ramosetron (0.3 mg) intravenously 10 min. before the administration spinal anaesthesia. 60 patients of age group 20-30 years, ASA Grade I \& ASA Grade II, body weight ranging from 45-65 kg were studied. All the patients were subjected to elective caesarean section or LLS under spinal anaesthesia. They were randomly allocated into two groups namely study group (30 patients received inj. ramosetron $0.3 \mathrm{mg}$ IV)and control group (30 patients received inj. ondansetron $4 \mathrm{mg}$ IV).Patients were observed intraoperatively, in the recovery room and in the ward up to 24 hours. For episodes of nausea and vomiting, Rescue antiemetic was given if the patients had PONV score 2 and was recorded. All the patients were observed for side-effects such as dizziness, headache, sedation or extrapyramidal reaction and accordingly up to 24 hours.

\section{RESULTS}

Incidence of nausea and vomiting in immediate postoperative period was $10 \%$ in study group compared to $20 \%$ in control group Dizziness and headache were comparable in both the groups.

\section{CONCLUSION}

Ramosetron is quite effective to prevent nausea and vomiting in LSCS \& LLS patients under spinal anaesthesia. It reduces the incidence of nausea and vomiting intraoperatively and in the immediate postoperative period.

\section{KEYWORDS}

Spinal Anaesthesia, Caesarean Section, Lower Limb Surgery, Ramosetron, Postoperative Nausea and Vomiting, Ondansetron.

HOW TO CITE THIS ARTICLE: Ray UK, Mandal PK. Role of ramosetron and ondansetron in LUCS and lower limb surgery under spinal anaesthesia. J. Evolution Med. Dent. Sci. 2018;7(02):228-232, DOI: 10.14260/jemds/2018/51

\section{BACKGROUND}

In lower segment caesarean section (LSCS) \& Lower limb surgery (LLS), spinal anaesthesia has become increasingly popular in recent years and is now a commonly performed surgical procedure. Regional anaesthesia is performed in $80 \%$ of anaesthetised patients compared to $20 \%$ who received general anaesthesia.[1,2] Consciousness allows the patients to enjoy the early immediate contact with the newborn child (bonding), the procedure may be associated with various important problems, ${ }^{[3]}$ like arterial hypotension, headache, insufficient anaesthesia and psychological distress. ${ }^{[4]} \mathrm{A}$ common problem in caesarean section \& LLS is intra and postoperative nausea and vomiting under regional

'Financial or Other Competing Interest': None.

Submission 10-11-2017, Peer Review 23-12-2017,

Acceptance 29-12-2017, Published 08-01-2018.

Corresponding Author:

Dr, Prasanta Kumar Mandal,

AT-Lokepur, P.O-Kendua Dihi

Dist. Bankura.

E-mail: drprasantamondal@gmail.com

DOI: $10.14260 /$ jemds $/ 2018 / 51$

\section{(c) $(1)$}

anaesthesia.[5,6] $72 \%$ of patients are afraid of nausea and vomiting and $71 \%$ feel significant discomfort. Previous reports and our observations suggest both nausea and vomiting as frequent phenomenon, with the incidences up to 80\%.[7,8] The major risk factors for nausea and vomiting during or after spinal anaesthesia in caesarean section \& lower limb surgeries is arterial hypotension due to blockade of the sympathetic nerve system. ${ }^{[9]}$ Critical anaesthesiological complications such as airway obstruction, aspiration pneumonitis, and wound dehiscence are rare and mainly related to postoperative nausea and vomiting in general surgical patients.[10,11,12] Nausea and vomiting may be influenced by hormonal changes in pregnancy, which alter the sphincter tone of the oesophagus and the stomach and the activity of small bowel and oesophagus, as well as adverse effects of uterotonic drugs, intraoperative manipulation of the uterus and psychological distress aggravated by insufficient anaesthesia.[13,14,15] Vomiting centre represents several nuclei in the brainstem (e.g. nucleus tractus solitarius, area postrema), which are responsible for the co-ordination of the efferent limb of the vomiting reflex. It receives input from the afferent limbs of the reflex and the area postrema. The area 
postrema is located at the caudal end of the floor of the fourth ventricle known as Chemoreceptor Trigger Zone (CTZ). Evidence from ablation studies by Borison and Wang in the 1950s and the fact that the blood-brain barrier is defective in this area suggest that the area postrema is responsible for detecting toxins circulating in the blood and cerebrospinal fluid. This function is the nearby nucleus tractus solitarius where dopamine and opioid receptors are abundant.[16]

Afferent limb of vomiting reflex from mechano- and chemoreceptors in the gastrointestinal tract is relayed via vagus nerve to the nucleus tractus solitarius in the brainstem. Abnormal gastric or intestinal distention, increased smooth muscle contraction and abnormal or toxic gastrointestinal contents can trigger the vomiting reflex. Peripheral 5- $\mathrm{HT}_{3}$ receptors are intimately involved. Radiation, chemotherapy and other toxins release 5-HT from chromaffin cells in the gut, which stimulates vagal afferents -a process inhibited by the 5- $\mathrm{HT}_{3}$ antagonist antiemetics. Afferent inputs also come from the vestibular system and the higher centres. Miscellaneous inputs come from nasopharyngeal tube, stimulation of the auricular branch of vagus and also pain pathways from the viscera reside in the splanchnic nerves and visceral pains. [Vide-Table-1, Vomiting reflex].

Nausea is not an inevitable consequence of vomiting but it is often a troublesome symptom after surgery and anaesthesia. However, a consistent finding is that antiemetic therapy is often very effective in reducing the incidence of vomiting or retching, but less so far nausea.

The potential adverse effects of PONV causes aspiration of stomach contents which increases the anaesthetic mortality and morbidity.

Oral administration of drugs (e.g. analgesics, antihypertensives), fluids and nutrients delay discharge from day care surgery and may disrupt neck, abdominal and eye sutures by PONV. A previous history of PONV, motion sickness, children and female gender are the major risk factors. Surgical factors associated with an increased risk of PONV are Gynaecological, ENT, Gastrointestinal, Head and Neck and squint surgery, duration of surgery and postoperative antibiotics. Perioperative use of opioids (oral, IM, epidural, spinal) is associated with an increased incidence of PONV and many anaesthetic techniques aim to avoid opioids for this reason. PONV may indicate postoperative hypotension, hypoxaemia, early fluid intake or mobilisation, psychological factors play an important role and may respond to appropriate non-pharmacological management. Dexamethasone and cannabinoids (e.g. nabilone, dronabinol) are effective against chemotherapy-induced emesis. Metoclopramide acts at the dopamine receptors in the stomach, upper intestine and CTZ. It enhances gastric emptying, intestinal transit and lower oesophageal sphincter pressure. The side effects of metoclopramide are extrapyramidal reactions, facial muscle spasm, trismus, oculogyric crises, opisthotonus hypotension, sinus tachycardia, supraventricular tachycardia.

Ondansetron was the first specific potent $5 \mathrm{HT}_{3}$ receptor antagonist available for PONV. Oral bioavailability is $60 \%$ and elimination half-life is $4 \mathrm{~h}$. Granisetron, tropisetron and dolasetron have similar pharmacological properties. Major advantages of $5 \mathrm{HT}_{3}$ receptor antagonists are wide therapeutic index, no extrapyramidal side-effects, no excessive sedation and no prolongation of recovery from anaesthesia.[17]
Many drugs are used for management of PONV but few of them have side effects like sedation, dryness of mouth, restlessness and tachycardia. $5 \mathrm{HT}_{3}$ receptors antagonists are devoid of such side-effects. Ondansetron, granisetron and newer drug such as ramosetron and palonosetron are commonly used drugs to prevent PONV.[18]

\section{Objectives}

To determine the efficiency of ramosetron and ondansetron in terms of prevention of nausea and vomiting intraoperatively and postoperatively in LSCS \& LLS patients under spinal anaesthesia in terms of prevention of nausea and vomiting intraoperatively and postoperatively.

\section{MATERIALS AND METHODS}

In this randomised, double-blind study, 60 patients received either ondansetron (4 $\mathrm{mg})$ or ramosetron $(0.3 \mathrm{mg})$ intravenously $10 \mathrm{~min}$. before the administration of spinal anaesthesia. The study was done at Murshidabad Medical College \& Hospital \& B. S. Medical College, Bankura, West Bengal during the period of July 2016 to June 2017. From the existing research, it was noted that around half of the patients who underwent spinal anaesthesia developed nausea and/or vomiting. Assuming the $50 \%$ reduction in nausea/vomiting by giving ramosetron over ondansetron, 95\% confidence level, the final sample size per group using the following formula was 27 , which was rounded off to $30 . n=Z \alpha 2^{*}[\mathrm{P} 1$ (1-P1) + P2(1-P2)]/ (P1-P2)2; where Z $\alpha$ for 95\% confidence level is $1.96, \mathrm{P} 1=0.5$ and $\mathrm{P} 2=0.25$.

So, 60 patients of age group 20-30 years, ASA Grade I \& ASA Grade II, body weight ranging from 45-65 kg were studied. All the patients were subjected to elective caesarean section \& LLS under spinal anaesthesia. Block randomisation method with a block of four was used to allocate patients into two groups namely study group (30 patients received inj. ramosetron $0.3 \mathrm{mg} \mathrm{IV}$ ) and control group (30 patients received inj. ondansetron $4 \mathrm{mg}$ IV) by the investigators and coded accordingly. The codes were neither disclosed to the concerned Anaesthetist and the team, nor to the patient. Patients with $\mathrm{H} / \mathrm{O}$ diabetes mellitus, allergic to local anaesthetic, with hepatic disorders and taking antiemetic medication were excluded in our study. After pre-anaesthetic evaluation and investigation, the patient was explained about the procedure. Informed consent was taken. Baseline vital parameters were recorded.

There were no significant differences between two groups regarding patients' characteristics (age, body weight, height and previous history of motion sickness and PONV), type of anaesthesia and preoperative starvation. All the patients were preloaded with RL $10 \mathrm{~mL} / \mathrm{kg}$ to prevent intraoperative hypotension followed by nausea and vomiting. All patients were premedicated with midazolam $3.75 \mathrm{mg}$ orally 1 hour before transfer to the operating theatre. Spinal anaesthesia was induced in sitting position between L3/L4 with $0.5 \%$ hyperbaric bupivacaine with 25/26G spinal needle. Dosage depended on the body height. Body height $150 \mathrm{~cm}$ resulted in $1.8 \mathrm{~mL}$ bupivacaine $0.5 \%$, every $5-\mathrm{cm}$ additional height resulted in an additional $0.2 \mathrm{~mL}$ bupivacaine dosage.

Patients were observed intraoperatively, in the recovery room and the ward up to 24 hours for episodes of nausea and vomiting or retching which were evaluated on 3-point PONV score (0- no nausea \& vomiting, 1- episode of nausea, 2- 
retching and vomiting) for next $24 \mathrm{hrs}$. Rescue antiemetic was given for the patients with PONV score 2 and was recorded. All the patients were observed for side-effects such as dizziness, headache, sedation or extrapyramidal reaction and treated accordingly up to 24 hours.

Data were analysed using unpaired " $t$ " test, chi square and chi square for trend test using MS excel and Epi Info 3.4 software and $\mathrm{p}$ value $<0.05$ was Considered Statistically Significant. Data was presented as mean \pm standard deviation and percentage.

\section{RESULTS}

There were 60 patients who underwent randomisation into two groups. 30 patients (Study group) received ramosetron and another 30 patients (Control group) received ondansetron. The demographic data with respect to age, sex, height and weight were comparable in both groups (Table 2). There was no statistically significant difference in respect to duration of surgery and duration anaesthesia in both the groups. When PONV score was 2, rescue antiemetic was given (i.e. $6.66 \%$ in study group). Incidence of side effects (headache, constipation and dizziness) was comparable in both the groups (Table 5).

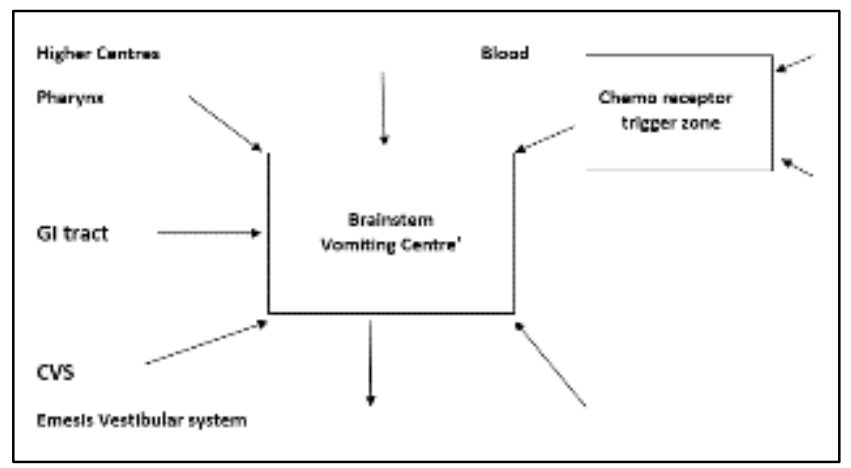

Figure 1. Shows the Vomiting Reflex

\begin{tabular}{|c|c|c|c|c|c|}
\hline \multicolumn{3}{|c|}{ Study Group } & \multicolumn{2}{|c|}{ Control Group } & P Value \\
\hline Age (Years) & \multicolumn{2}{|c|}{$24.22 \pm 2.56$} & \multicolumn{2}{|c|}{$24.66 \pm 2.62$} & $\mathrm{P}>0.05 \mathrm{NS}$ \\
\hline Height $(\mathrm{Cm})$ & \multicolumn{2}{|c|}{$154.36 \pm 8.86$} & \multicolumn{2}{|c|}{$157.42 \pm 9.56$} & $\mathrm{P}>0.05 \mathrm{NS}$ \\
\hline Weight (Kg) & \multicolumn{2}{|c|}{$65.2 \pm 4.8$} & \multicolumn{2}{|c|}{$64.2 \pm 4.6$} & $\mathrm{P}>0.05 \mathrm{NS}$ \\
\hline $\begin{array}{c}\text { Duration of } \\
\text { Surgery (min.) }\end{array}$ & \multicolumn{2}{|c|}{$40.26 \pm 6.6$} & \multicolumn{2}{|c|}{$41.43 \pm 6.8$} & $\mathrm{P}>0.05 \mathrm{NS}$ \\
\hline \multicolumn{6}{|c|}{ NS-Not Significant. } \\
\hline \multicolumn{6}{|c|}{ Table 2. Demographic Profile } \\
\hline \multicolumn{4}{|c|}{ Study Group } & \multicolumn{2}{|c|}{ Control Group } \\
\hline \multicolumn{2}{|c|}{$\begin{array}{c}\text { No. of } \\
\text { Patients } \\
(n=30)\end{array}$} & \multicolumn{2}{|l|}{$\%$} & $\begin{array}{c}\text { No. of } \\
\text { Patients } \\
(n=30)\end{array}$ & $\%$ \\
\hline $\begin{array}{c}\text { Nausea } \\
\text { Immediately }\end{array}$ & 3 & $10 \%$ & & 6 & $20 \%$ \\
\hline 0-3 hrs. & 2 & 6.660 & & 3 & $10 \%$ \\
\hline 3-6 hrs. & 0 & $0 \%$ & & 2 & $6.66 \%$ \\
\hline 6-12 hrs. & 0 & $0 \%$ & & $0 \%$ & $0 \%$ \\
\hline 12-24 hrs. & 1 & $3.3 \%$ & & 2 & $6.66 \%$ \\
\hline Total & 6 & $\overline{19.96}$ & & 13 & $42.32 \%$ \\
\hline Table 3. & Naus & $\begin{array}{l}\text { of Po } \\
\text { First }\end{array}$ & & $\begin{array}{l}\text { Exper } \\
\text { urs }\end{array}$ & \\
\hline
\end{tabular}

\begin{tabular}{|c|c|c|c|c|}
\hline \multicolumn{2}{|c|}{ PONV Score Study Group } & \multicolumn{2}{c|}{ Control Group } \\
\hline & No (n=30) & (\%) & NO (n=30) & (\%) \\
\hline $\begin{array}{c}\text { 0(No nausea } \\
\text { \& vomiting) }\end{array}$ & 22 & $(73.34 \%)$ & 14 & $(46.67 \%)$ \\
\hline $\begin{array}{c}\text { 1(Episode of } \\
\text { vomiting) }\end{array}$ & 6 & $(20 \%)$ & 11 & $(36.67 \%)$ \\
\hline $\begin{array}{c}\text { 2 (Episode of } \\
\text { retching, } \\
\text { vomiting) }\end{array}$ & 2 & $(6.66 \%)$ & 5 & $(16.67 \%)$ \\
\hline Total & $\mathbf{3 0}$ & $\mathbf{( 1 0 0 \% )}$ & $\mathbf{3 0}$ & $\mathbf{( 1 0 0 \% )}$ \\
\hline \multicolumn{5}{|c|}{ Table 4. PONV Score } \\
\hline
\end{tabular}

Chi square for trend $=4.105 ; \mathrm{p}=0.0427$

\begin{tabular}{|c|c|c|c|c|}
\hline \multicolumn{6}{|c|}{ Study Group } & Control Group \\
\hline \multicolumn{5}{|c|}{ Complications } \\
\hline No (n=30) & $(\%)$ & NO(n=30) & $(\%)$ \\
\hline Dizziness & 11 & $(36.66 \%)$ & 9 & $(30 \%)$ \\
\hline Headache & 6 & $(20 \%)$ & 5 & $(16.66 \%)$ \\
\hline \multicolumn{5}{|c|}{ Satisfaction } \\
\hline Satisfied & 24 & $(80 \%)$ & 18 & $(60 \%)$ \\
\hline Unsatisfied & 6 & $(20 \%)$ & 12 & $(40 \%)$ \\
\hline \multicolumn{3}{|c|}{ Table 5. Side Effects and Patient Satisfaction } \\
\hline
\end{tabular}

Chi $\mathrm{sq}=2.86 ; \mathrm{p}=0.09$

In the early postoperative period (immediately), the incidence of nausea was $20 \%$ in the control group and was $10 \%$ in study group. Within $0-3 \mathrm{hrs}$., the incidence of nausea was $10 \%$ in control group and $6.66 \%$ in study group. Within $12-24 \mathrm{hrs}$., the incidence of nausea was $6.66 \%$ in control group and $3.3 \%$ in study group.

PONV score 0 (no nausea \& vomiting) was observed in $53.34 \%$ in control group and $73.34 \%$ in study group. PONV score 2 (Episode of retching, vomiting) was $13.33 \%$ in control group and $6.66 \%$ in study group. Dizziness was 30\% in control group and $36.66 \%$ in study group. Patient's satisfaction was $80 \%$ in study group and $60 \%$ in control group.

\section{DISCUSSION}

The study was conducted on the background that an optimal perioperative patient comfort is of outstanding interest and nausea \& vomiting with average incidence of $30 \%$ is rated as one of the most undesirable events in the context of surgery and anaesthesia.[19,20,21] Therefore, every attempt should be made, especially in context of birth, to avoid this complication, which is an unpleasant adverse effect, but also may cause severe complications such as wound dehiscence, dehydration, aspiration or pneumothorax.[10,11] There were no definite studies performed regarding comparison of ramosetron and ondansetron in LSCS \& LLS patients under spinal anaesthesia.

In our study, we have observed number of patients who had episodes of nausea and vomiting in LSCS \& LLS patients under spinal anaesthesia. Ramosetron, recently developed elective $5 \mathrm{HT}_{3}$ receptor antagonist. It shows significantly greater affinity for $5 \mathrm{HT}_{3}$ receptors, resulting in more potent, longer receptor antagonising effects compared to older $5 \mathrm{HT}_{3}$ antagonist. [22,23]

Ramosetron is more potent and has longer duration of action than granisetron in prevention of emesis after Cisplatin therapy and prevention of PONV.[24] 
Choi and Colleagues reported that ramosetron IV was better than ondansetron IV in reducing the severity of nausea, incidence of vomiting and the rescue antiemetics at 6-24 hrs. after operation in patients who have undergone spinal surgery.[25]

PONV score was 0 in $73.4 \%$ patients in study group (Ramosetron group) as compared to $53.4 \%$ patients in control group (Ondansetron group) in our study.

It suggests that ramosetron is quite effective in controlling nausea and vomiting in both intraoperative and postoperative period.

Fujii et al reported that ramosetron is effective in preventing PONV after major gynaecological surgery.[26]

In our study, ramosetron $0.3 \mathrm{mg}$ was effective in reducing the incidence of PONV (26.66\% in study group versus $46.66 \%$ in control group).

Kim et al performed similar study in gynaecological surgery and they have observed similar results as well.[27]

The most frequently reported adverse events of 5HT3 receptor antagonists are dizziness and headache. ${ }^{[28]}$ Adverse events observed in our study were similar in both the study and control groups.

\section{CONCLUSION}

On the basis of the present study, it can be concluded that inj. ramosetron $0.3 \mathrm{mg}$ IV is much more effective for prevention of postoperative nausea and vomiting in LSCS and LLS patients under spinal anaesthesia. Ramosetron seems to be a useful alternative and relatively a safe drug for effective antiemetic prophylaxis. It also reduces the PONV score and incidence of nausea in both the groups.

\section{ACKNOWLEDGEMENTS}

We are thankful to all the staff members and interns \& residents of Department of Anaesthesia, Obstetrics and Gynaecology and Dept. of Orthopaedics for their support. We are also thankful to our patients for being a part of our study.

\section{REFERENCES}

[1] Bowring J, Fraser N, Vause $\mathrm{S}$, et al. Is regional anaesthesia better than general anaesthesia for caesarean section? Obstet Gynaecol 2006;26(5):433-4.

[2] Jekins JG, Khan MM. Anaesthesia for caesarean section: a survey in a UK region from 1992 to 2002. Anaesthesia 2003;58(11):1114-8.

[3] Ratcliffe FM, Evans JM. Neonatal well-being after elective caesarean delivery with general, spinal and epidural anaesthesia. Eur J Anaesthesiol 1993;10(3):175-81.

[4] Tarkkila PJ, Kaukinen S. Complications during spinal anaesthesia: a prospective study. Reg Anesth 1991;16(2):101-6.

[5] Santos A, Datta S. Prophylactic use of droperidol for control of nausea and vomiting during spinal anaesthesia for caesarean section. Anesth Analg 1984;63(1):85-7.

[6] Harmon D, Ryan M, Kelly A, et al. Acupressure and prevention of nausea and vomiting during and after spinal anaesthesia for caesarean section. Br J Anaesth 2000;84(4):463-7.
[7] Lussos SA, Bader AM, Thornhill ML, et al. The antiemetic efficacy and safety of prophylactic metoclopramide for elective caesarean delivery during spinal anaesthesia. Reg Anesth 1992;17(3):126-30.

[8] Abouleish EL, Rashid S, Haque S, et al. Ondansetron versus placebo for the control of nausea and vomiting during caesarean section under spinal anaesthesia. Anaesthesia 1999;54(5):479-82.

[9] Balki M, Carvalho JC. Intraoperative nausea and vomiting during caesarean section under regional anaesthesia. Int J Obstet Anesth 2005;14(3):230-41.

[10] Schumann R, Polaner DM. Massive subcutaneous emphysema and sudden airway compromise after postoperative vomiting. Anesth Analg 1999;89(3):7967.

[11] Bremner WG, Kumar CM. Delayed surgical emphysema, pneumomediastinum and bilateral pneumothorasis arter postoperative vomiting. $\mathrm{Br}$ J Anaesth 1993;71(2):296-7.

[12] Mishriky BM, Habib AS. Metoclopramide for nausea and vomiting prophylaxis during and after caesarean delivery: a systemic review and meta-analysis. $\mathrm{Br} \mathrm{J}$ Anaesth 2012;108(3):374-83.

[13] Broussard CN, Richter JE. Nausea and vomiting of pregnancy. Gastroenterol Clin North Am 1998;27(1):123-51.

[14] Koch KL, Frissora CL. Nausea and vomiting of pregnancy. Gastroenterol Clin North Am 2003;32(1):201-34, vi.

[15] Wahab MA, Karantzis P, Essersley PS, et al. A randomized, control study of uterine exteriorization and repair at caesarean section. Br J Obstet Gynaecol 1999;106(9):913-6.

[16] Habib AS, Gan TJ. Evidence-based management of postoperative nausea and vomiting: a review. Canadian Journal of Anaesthesia 2004;51(4):326-41.

[17] Gan TJ Mayer T, Apfel CC, et al. Consensus guidelines for managing postoperative nausea and vomiting. Anaesthesia and Analgesia 2003;97(1):62-71.

[18] Tripathi KD. Prostaglandins, leukotrienes (eicosanoids) and platelet activating factor. In: Tripathi KD 2. edr. Essential of medical pharmacology. $6^{\text {th }}$ edn New Delhi: Jaypee Brothers Medical Publishers 2009:174-81.

[19] Rabasseda X. Ramosetron, a 5-HT3 receptor antagonist for the control of nausea \& vomiting. Drugs Today (Barc) 2002;38(2):75-89.

[20] Koivuranta M, Larra E, Snare L, et al. A survey of postoperative nausea and vomiting. Anaesthesia 1997;52(5):443-9.

[21] Palazzo M, Evans R. Logistic regression analysis of fixed patient factors for postoperative sickness: a model for risk assessment. $\mathrm{Br} \mathrm{J}$ Anaesth 1993;70(2):135-40.

[22] Fujii Y, Saitoh Y, Tanaka H, et al. Comparison of ramosetron and granisetron for preventing postoperative nausea and vomiting after gynaecological surgery. Anesth Analg 1999;89(2):4769.

[23] Scuderi PE, Conlay LA. Postoperative nausea and vomiting and outcome. Int Anesthesiol Clin 2003;41(4):165-74. 
[24] Kang YK, Park YH, Ryoo BY, et al. Ramosetron for the prevention of cisplatin-induced acute emesis: a prospective randomized comparison with granisetron. J Int Med Res 2002;30(3):220-9.

[25] Choi YS, Shim JK, Yoon DH, et al. Effects of ramosetron on patient-controlled analgesia related nausea and vomiting after spine surgery in highly susceptible patients: comparison with ondansetron. Spine (Phila Pa 1976) 2008;33(17):E602-6.

[26] Fujii Y, Saitoh Y, Tanaka H, et al. Ramosetron for preventing postoperative nausea and vomiting in women undergoing gynecological surgery. Anesth Analgh 2000;90(2):472-5.
[27] Kim SL, Kim SC, Baek YH, et al. Comparison of ramosetron with ondansetron for prevention of postoperative nausea and vomiting in patients undergoing gynaecological surgery. $\mathrm{Br} \mathrm{J}$ Anesh 2009;103(4):549-53.

[28] Makenzie R, Kovac A, O'Connor T, et al. Comparison of ondansetron versus placebo to prevent postoperative nausea and vomiting in women undergoing ambulatory gynecological surgery. Anesthesiol 1993;78(1):21-8. 